\title{
LÉVY-KHINTCHINE REPRESENTATION OF THE GEOMETRIC MEAN OF MANY POSITIVE NUMBERS AND APPLICATIONS
}

\author{
FEng Qi, XiAO-Jing ZHANG, AND WEN-Hui Li
}

Abstract. In the paper, the authors establish, by Cauchy integral formula in the theory of complex functions, Lévy-Khintchine representation for the geometric mean of many positive numbers, find that the geometric mean of many positive numbers is a complete Bernstein function, and supply a new proof of the well known arithmetic-geometric mean inequality.

Mathematics subject classification (2010): Primary 26E60; Secondary 26A48, 30E20, 44A10, 44A20. Keywords and phrases: Lévy-Khintchine representation; integral representation; geometric mean; completely monotonic function; logarithmically completely monotonic function; Bernstein function; complete Bernstein function; Cauchy integral formula; arithmetic-geometric mean inequality.

\section{REFERENCES}

[1] R. D. Atanassov and U. V. Tsoukrovs Ki, Some properties of a class of logarithmically completely monotonic functions, C. R. Acad. Bulgare Sci. 41 (1988), no. 2, 21-23.

[2] E. F. Beckenbach, R. E. Bellman, Inequalities, Ergebnisse der Mathematik und ihrer Grenzgebiete, N. F., Bd. 30, Springer-Verlag, Berlin, 1961 and 1983.

[3] C. BERG, Integral representation of some functions related to the gamma function, Mediterr. J. Math. 1 (2004), no. 4, 433-439; Available online at http://dx.doi.org/10.1007/s00009-004-0022-6.

[4] P. S. Bullen, Handbook of Means and Their Inequalities, Mathematics and its Applications, Volume 560, Kluwer Academic Publishers, Dordrecht-Boston-London, 2003.

[5] C.-P. Chen, F. QI, And H. M. SRivastava, Some properties of functions related to the gamma and psi functions, Integral Transforms Spec. Funct. 21 (2010), no. 2, 153-164; Available online at http://dx.doi.org/10.1080/10652460903064216.

[6] T. W. Gamelin, Complex Analysis, Undergraduate Texts in Mathematics, Springer, New YorkBerlin-Heidelberg, 2001.

[7] B.-N. GUO AND F. QI, A property of logarithmically absolutely monotonic functions and the logarithmically complete monotonicity of a power-exponential function, Politehn. Univ. Bucharest Sci. Bull. Ser. A Appl. Math. Phys. 72 (2010), no. 2, 21-30.

[8] G. H. Hardy, J. E. Littlewood, and G. Pólya, Inequalities, 2nd ed., Cambridge University Press, Cambridge, 1952.

[9] J.-C. KuANG, Chángyòng Bùděngshì (Applied Inequalities), 3rd ed., Shāndōng Kēxué Jìshù Chūbăn Shè (Shandong Science and Technology Press), Ji’nan City, Shandong Province, China, 2004. (Chinese)

[10] D. S. Mitrinović, Analytic Inequalities, Springer, New York-Heidelberg-Berlin, 1970.

[11] F. QI, Integral representations and properties of Stirling numbers of the first kind, J. Number Theory 133 (2013), no. 7, 2307-2319; Available online at http://dx.doi.org/10.1016/j.jnt.2012.12.015.

[12] F. QI, P. CERONE, AND S. S. DRAGOMIR, Complete monotonicity of a function involving the divided difference of psi functions, Bull. Aust. Math. Soc. 88 (2013), no. 2, 309-319; Available online at http://dx.doi.org/10.1017/S0004972712001025.

[13] F. QI AND C.-P. CHEN, A complete monotonicity property of the gamma function, J. Math. Anal. Appl. 296 (2004), no. 2, 603-607; Available online at http://dx.doi.org/10.1016/j.jmaa.2004.04.026. 
[14] F. QI AND S.-X. Chen, Complete monotonicity of the logarithmic mean, Math. Inequal. Appl. 10 (2007), no. 4, 799-804; Available online at http://dx.doi.org/10.7153/mia-10-73.

[15] F. QI AND B.-N. GUO, Complete monotonicities of functions involving the gamma and digamma functions, RGMIA Res. Rep. Coll. 7 (2004), no. 1, Art. 8, 63-72; Available online at http://rgmia.org/v7n1.php.

[16] F. QI, S. GuO, AND B.-N. GuO, Complete monotonicity of some functions involving polygamma functions, J. Comput. Appl. Math. 233 (2010), no. 9, 2149-2160; Available online at http://dx.doi.org/10.1016/j.cam.2009.09.044.

[17] F. QI, Q.-M. LuO, AND B.-N. GuO, Complete monotonicity of a function involving the divided difference of digamma functions, Sci. China Math. 56 (2013), no. 11, 2315-2325; Available online at http://dx.doi.org/10.1007/s11425-012-4562-0.

[18] F. QI, C.-F. WEI, AND B.-N. GUO, Complete monotonicity of a function involving the ratio of gamma functions and applications, Banach J. Math. Anal. 6 (2012), no. 1, 35-44.

[19] F. QI, X.-J. ZHANG, AND W.-H. LI, A new proof of the geometric-arithmetic mean inequality by Cauchy's integral formula, available online at http://arxiv.org/abs/1301.6432.

[20] F. QI, X.-J. ZHANG, AND W.-H. LI, An integral representation for the weighted geometric mean and its applications, Acta Math. Sin. (Engl. Ser.) 30 (2014), in press; Available online at http://dx.doi.org/10.1007/s10114-013-2547-8.

[21] F. QI, X.-J. Zhang, AND W.-H. LI, Lévy-Khintchine representations of the weighted geometric mean and the logarithmic mean, Mediterr. J. Math. (2014), in press; Available online at http://dx.doi.org/10.1007/s00009-013-0311-z.

[22] F. QI, X.-J. ZhANG, AND W.-H. LI, The geometric mean is a Bernstein function, http://arxiv.org/abs/1301.6848

[23] F. QI, X.-J. ZHANG, AND W.-H. LI, Some Bernstein functions and integral representations concerning harmonic and geometric means, available online at http://arxiv.org/abs/1301.6430.

[24] R. L. SCHILling, R. SONG, ANd Z. VONDRAČEK, Bernstein Functions-Theory and Applications, de Gruyter Studies in Mathematics 37, De Gruyter, Berlin, Germany, 2010.

[25] R. L. Schilling, R. Song, And Z. VondraČEK, Bernstein Functions-Theory and Applications, 2nd ed., de Gruyter Studies in Mathematics 37, Walter de Gruyter, Berlin, Germany, 2012.

[26] D. V. Widder, The Laplace Transform, Princeton University Press, Princeton, 1946.

[27] X.-J. Zhang, Integral Representations, Properties, and Applications of Three Classes of Functions, Thesis supervised by Professor Feng Qi and submitted for the Master Degree of Science in Mathematics at Tianjin Polytechnic University in January 2013. (Chinese) 